Portland State University

PDXScholar

3-2-2017

\title{
Clientelism and Citizens' Right to the City in the Province of Buenos Aires
}

\section{Sara Hyman}

Portland State University

Follow this and additional works at: https://pdxscholar.library.pdx.edu/honorstheses

\section{Let us know how access to this document benefits you.}

\section{Recommended Citation}

Hyman, Sara, "Clientelism and Citizens' Right to the City in the Province of Buenos Aires" (2017).

University Honors Theses. Paper 357.

https://doi.org/10.15760/honors.350

This Thesis is brought to you for free and open access. It has been accepted for inclusion in University Honors Theses by an authorized administrator of PDXScholar. Please contact us if we can make this document more accessible: pdxscholar@pdx.edu. 


\section{Clientelism and Citizens' Right to the City in the Province of Buenos Aires}

Sara Hyman

\section{ABSTRACT}

This research examines the relationship between neoliberalism, clientelism, and citizen's right to the city in the province of Buenos Aires. In the early 1990s a wave of neoliberal economic reform swept through Argentina. The social ramifications of this economic restructuring left many citizens marginalized and disenfranchised. In order to make ends meet, poor citizens exchanged their votes to receive basic necessities in a practice called clientelism. Urban clientelism, or the exchange of votes for goods, is analyzed within the theoretical understanding of Henri Lefebvre's right to the city. Ethnographic accounts detailing the relationship between clientelist brokers and community residents in Buenos Aires are examined through the lens of Lefebvre's ideals. In the relationship of clientelism, the relationship between state brokers and community residents demonstrate how clientelism puts democracy at risk. When placed in the framework of Lefebvre, clientelism is shown to be a perversion of the right to the city. 
Argentina has a complex history with democracy. After years of military dictatorships, Carlos Menem (1989-1999) became the first president in a democratic exchange of power. He inherited a government suffering from macro-economic instability, high inflation, and sluggish growth. In order to combat the flailing economy, Menem implemented wide spread reforms consistent with the practices of the Washington Consensus and neoliberalism (Rodríguez-Boetsch, 2005). These neoliberal practices have resulted in social and economic fragmentation, which have in turn contributed to endemic clientelism.

The central themes of this paper are neoliberalism, clientelism. They are the academic terms ascribed to lived experiences in Buenos Aires. Neoliberalism is defined by economic policies characterized by an opening of the markets, massive centralization, privatization, reductions in government spending, and austerity measures (Williamson, 1990). Clientelism is the exchange of political favors and votes to receive basic necessities (Stokes, 2011). These two separate terms have a linked history in the context of the province Buenos Aires, and are crucial to understanding the current political climate.

In this paper, I examine how citizenship is affected by clientelism, specifically focusing on the relationship between brokers and citizens. Urban citizenship here is defined using Henri Lefebvre's concept of "right to the city," which is premise that citizens have democratic access and claims to the city. This claim means that citizens have the inherent and self-conscience right to engage in the city politically, in public space, and through using resources available, such as access to food, health care, green spaces, and education (Lefebvre, 1981). According to Lefebvre, "the right to the city is 
like a cry and a demand... a transformed and renewed right to urban life" (Lefebvre, 1996). When acting upon their right to the city, residents can move about freely in public space without fear. Basic resources like food and medicine are not restricted to them. The community experiences a transformed and renewed right to urban life compared to tolerating and maneuvering the political systems of clientelism.

My research questions whether the structures of clientelism, particularly in the context of neoliberalism, undermine basic citizen rights. In order to answer this question, I examine how clientelist relationships operate in the province of Buenos Aires, giving emphasis to the relationship between the brokers and the citizens. Secondly, I build off of Lefebvre and other academics' arguments around the "right to the city" and examine how clientelism undermines this right in the Argentine context. Last, I discuss if clientelism in Argentina gives citizens a false positive perception of their own citizenship and rights to the city.

\section{History and Context}

Neoliberalism in Latin America arose from the Washington Consensus. Rooted in the International Monetary Fund, the World Bank, and US treasury, the WA Consensus was a set of economic policy deregulations prescribed to countries in crisis. The elements prescribed are a payment of debts and avoidance of fiscal deficits, priority in public expenditures, tax reforms to increase revenues as a solution to fiscal deficit, stable interest rates, a competitive exchange rate, a trade policy that focuses on import liberalization, direct investment from foreign markets, the privatization of industries to relieve pressure on government budget, and deregulation of markets (Williamson, 1990). The practices of the Washington Consensus constitute the set of demands the North 
imposes on the Global South. At their core, they are essentially defined by privatization, deregulation, and trade liberalization.

While the neoliberal experiment was present in all of Latin America, the examples of Mexico and Chile's economic restructuring in the 1970s have greatly impacted Buenos Aires. Both countries experienced initial success in foreign investment growth and pegging their currency to the US dollar. With time, however, both experiments in neoliberalism failed. Each country defaulted on large foreign debts, causing a chain reaction of foreign investors withdrawing financially from other Latin American countries. The rapid withdrawal of foreign investment and subsequent economic crises is known as the "tequila effect" (Budds, 2013; Dello Buono \& Lara, 2006; Medeiros, 2011) .

In the middle of the neoliberal experiment lies Argentina. Menem's government mirrored Chile's ruthless implementation of neoliberal policies. During the early 1990s, his convertibility plan, privatization, and deregulation attracted foreign investors and there was a decrease in the inflation rate and poverty (Vilas, 2006). However, with Mexico and Chile beginning to default on their loans, foreign investors were scared off and suddenly withdrew from Argentina, contributing to further financial instability and the ultimate crisis of December 2001.

While Argentina initially grew in foreign investors in the opening of their markets under neoliberalism, this led to an unequal distribution of wealth socially. The economic crisis was a result of this economic disparity in addition to the withdrawal of foreign investors. "By October 2001, the richest $10 \%$ of households in the Buenos Aires Metropolitan Area accounted for the same portion of income than the poorest $60 \%$ of 
households in the same area. Their income level was almost 34 times higher than that of the poorest $10 \%$ of households" (Vilas, 2006). There was a combined national deterioration because of neoliberal policies combined with a social upheaval over the rising level of poverty.

The neoliberal macroeconomic policies implemented had a unique impact on the citizens of Argentina, especially the poor. Although Menem's government denied the existence of growing poverty, unemployment went from 1.6 million in 1990 to 4 million in 2000; those living below the poverty line rose from $12.7 \%$ of the population in 1986 to $49.7 \%$ in 2002 , and it is estimated that in $2016,400,000$ people live without at least two basic services (e.g. adequate housing, food, water, etc.) (Auyero, 2010; Jenkinson, 2016.).

High national debt and heavy centralization from the government meant fewer funds for those struggling in the country. In the wake of defaulting on the debt of US\$140 billion and devaluing the currency by more than $300 \%$, Argentina struggled to support marginalized members of society ("2001-2011: The Making of a Crisis,” 2011). Under the expanse of growing poverty in Menem's time, the term "poor" was reserved only for the most marginal members of society. The poverty line was once defined as the basic food basket combined with costs of transportation, schooling, and housing. As Menem redefined social welfare, only those people who were "indigent" were called poor (Grassi $\&$ Noberto, 2005; Ratliff \& Fontaine, 1993). If a family was indigent, they did not have enough income to buy even a basic food basket for their family (Amadasi, 1999). Under Menem, the very definition of poor changed. 
As the government centralized financially and socially, people who previously benefitted from the welfare state found themselves without resources. The poor, those who had been pushed out of the city limits and lived below the line of indigence, and the "new poor," those who suffered chronic unemployment and loss of status but did not qualify as indigent, were forced into clientelist relationships where they traded their votes and political favors with government officials in order to receive basic necessities. The practice of clientelism is nothing new to Argentina; however its existence in the democratic era of the country and its persistence beyond Menem's years are cause for concern.

Clientelism is the relationship between the citizens of a community who exchange political and personal favors with state brokers in order to receive basic goods from the state (Stokes, 2011; Szwarcberg, 2012). Residents receive fundamental necessities on the condition that they support a specific political party or person. The conditional relationship between residents and the politicians who represent them opposes the basic concept of civil society. In civil society, it is assumed citizens have relative autonomy in their communities. It implies civic engagement and involvement to decide the shape of the community. It requires representation in the government to be in close contact with their constituents to fight for their demands. Clientelism subverts this idea. It denies citizens the capacity to participate fully in their communities and instead forces them to rely on the government.

Classical definitions of clientelism focus on the problem from a standpoint of power politics. Paradiso explains that clientelism is a "form of social and political organization where access to public resources is controlled by powerful 'patrons' and is 
delivered to less powerful 'clients' in exchange for deference and other forms of service" (Paradiso, 2016). In the case of Argentina, clientelism is not just a power exchange of votes for basic infrastructure and necessities. The inherent relational aspect of clientelism has made it into a problem-solving social network. In this network, the poor address their everyday survival needs through "personalized political mediation" rather than through collective action (Auyero, 2000b). While clientelism is deeply rooted in the remnants of the Peronist party, the connection between the brokers, or middle-men, and the citizens of the community has become much more than a political relationship (M. Szwarcberg, 2012).

In a time of scarce resources and welfare, clientelism became an opportunistic method of using what little resources are available. As Brusco et al. points out in their article, "Clientelist networks are sort of a poor country's welfare state. Reform such systems too soon, the minority asserts, and you run the danger of depriving 'clients' of the only organizations and networks capable of responding to their needs" (Brusco, Nazareno, \& Stokes, 2004).

One of the benefits of clientelism is that it manufactures a network where scarcity and isolation are otherwise dominant. Citizens are grateful for any resources provided by the state. The debt of gratitude established in their linkages makes the relationship not transactional, but more of a personal connection. The experience of gratitude breeds loyalty and faithfulness to the providing party. The relationship is not strictly a power dynamic, but instead a way for community members to manipulate the system in order to receive goods. Often community leaders are the ones who become brokers in order to navigate the murky waters of scarce social resources. Clientelism provides citizens with a 
network of resources otherwise unavailable (Auyero, 2000b; Szwarcberg, 2012; WeitzShapiro, 2014).

Citizens have a small amount of leverage as they navigate the systems of clientelism. Those in power desire to remain in power, and it is more likely that they will remain there if they implement practices of vote-buying and favor exchanges (Szwarcberg, 2015). Citizens capture a small amount of power because politicians rely on their support and votes. Many communities have a strong Peronist political affiliation, such as those in the ethnographies of Auyero. Those who do not have direct political affiliation are able to choose whom to give their votes to (Szwarcberg, 2012). The residents can potentially use their votes as a bargaining tool for different political parties to compete for their support. In the end, however, this can be a costly game. If the community's requests are too big, they may end up receiving no resources at all. Political parties always have the upper hand and come out ahead in terms of stability.

Lefebvre's ideal of the right to the city stands in stark contrast to the technocratic reality of clientelism. Clientelism is an exclusionary system implemented by the state. The language used to determine who receives resources, the formality of government officials entering into poor communities through the use of brokers, and the process of scarce resource distribution all function within a system of exclusion. Clientelism becomes a form of domination in a seemingly non-coercive way. The reality is, when people have no choice in their actions, the domination is coercive. Clientelism ultimately perpetuates uneven power structures as the norm, patronizes citizens, and is the power dynamic response to social distribution. 
The right to the city is the democratic vision for urban society. This right endorses citizen capacities and individual power and their ability to participate. A democratic community signifies that members actively participate; there is civic engagement, consensus building, and representation in a larger government. The right to the city is founded within the set of ideas underpinning community involvement and collaboration for collective gains. In areas afflicted by clientelism it is difficult to imagine what these types of freedoms would look like. In the case of greater Buenos Aires, perhaps the residents would be able to start their own community clinic, create their own community center, or form an informal network between families to cook and care for aging members of the community without transactional support from the government. This right emphasizes self-governance, empowerment, and depends on citizens' ability to shape their own community instead of having it shaped for them. It implies a relative degree of autonomy and self-determination for the community compared to dependency on the state.

\section{Theory and Methods}

I analyze greater Buenos Aires's urban clientelism within the theoretical understanding of right to the city literature. I rely upon ethnographic accounts and literature from key authors to understand the relationship between citizens and brokers. On the theme of the right to the city, I integrate the original theory writings of Lefebvre with other academic literature that uses his theory to examine urban contexts.

The most cited sources in the conversation around clientelism in Argentina are Javier Auyero, Maria Szwarcberg, and Rebecca Weitz-Shapiro. Auyero details in his ethnography how clientelism and problem-solving networks have been maintained. He 
brings new insight into the conversation through his discussion of how both the clients and brokers view these transactional relationships. Similarly, Szwarcberg employs an ethnographic appeal to speak to the potency of clientelism and she classifies politicians based on their reliance on clientelism. Weitz-Shapiro explains in detail why certain politicians opt in or out in the use of clientelist practices. According to her research, politicians ultimately continue to use clientelist practices because they win with them. She showed that politicians who did not engage in clientelism were not re-elected to a second term compared to parties that employed vote buying tactics remained in power for years at a time (Weitz-Shapiro, 2014).

While their works have different emphases, all of these core authors provide critical insight into the relationship between brokers, i.e. those state actors who engage in the exchange of favors, and the residents of the impoverished areas on the outskirts of society. The accounts of these authors resonate with the current political affairs of Argentina. Their ethnographies were all conducted post-crisis (2001 onward). Additionally, all three authors agree that the practice of clientelism undermines democracy. Szwarchberg summarizes their common finding in this way, "Clientelism matters because in buying the political participation of poor voters, the quality of political democracy suffers" (Szwarcberg, 2009).

My research relies heavily on the ethnographies of Auyero, Szwarcberg, and Weitz-Shapiro. These authors focus on clientelism in the Greater Buenos Aires area (see Figure 1). This area includes the municipalities outside the capital city of Buenos Aires that are still under the administrative power of the capital city and its government. More specifically, my examples and substantiation are drawn from the ethnographies based in 
Villa Paraíso, Jose C. Paz, General San Martín, Malvinas Argentinas, and San Miguel (Auyero, 2000a; Szwarcberg, 2015; Weitz-Shapiro, 2008). These ethnographic accounts are the foundation of my research and conclusions.

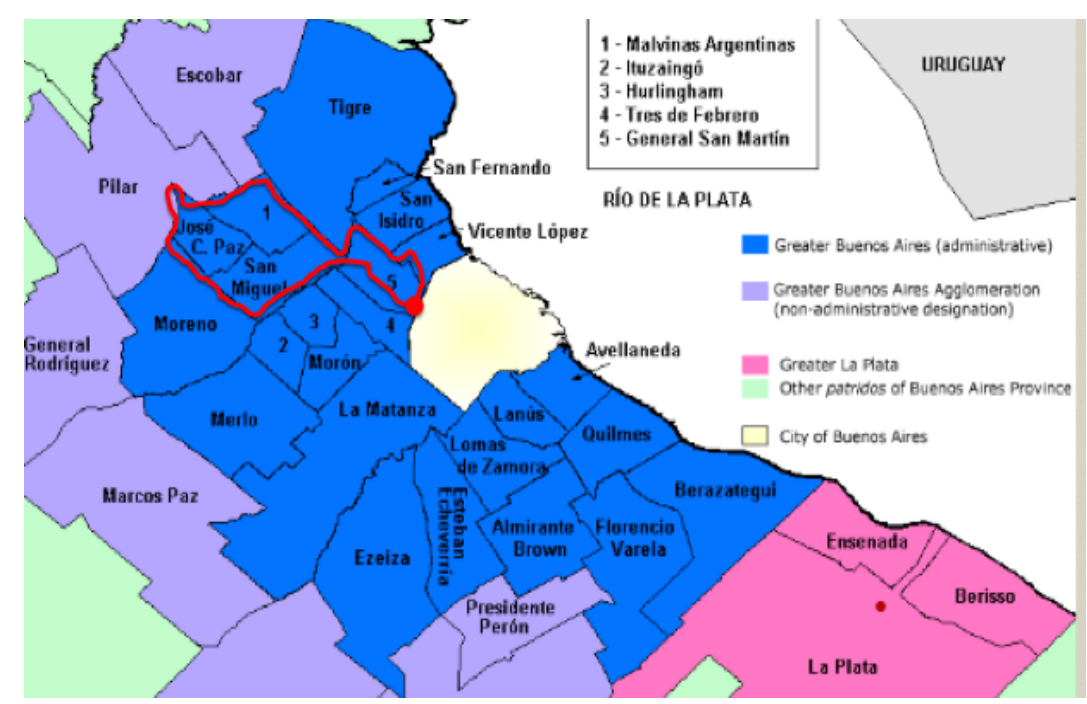

Figure 1: Map of Greater Buenos Aires with Areas of Ethnographies in Red

The academic discourse around clientelism proposes that it is not democratic and its existence may be controversial in democratic states. Democracy has been defined historically by the involvement of citizens, public participation, community engagement, citizen representation and a government for the people. The "right to the city" is designed for citizen empowerment. The meaning of "right to the city" here is principally drawn from Henri Lefebvre's Writings On Cities, and was popularized by David Harvey in Rebel Cities among his other writings. Harvey concisely defines this right as a "right to change and reinvent the city after our heart's desires" (Harvey, 2012). A component of this right is that citizenship can be defined by a person's ability to benefit from the urbanization process.

Beyond Harvey, contemporary authors summarize what this right to the city looks like in practice. Cutts \& Moser explain, 
The "right to the city" encompasses many different rights, broadly based on equitable access to the benefits, services, and opportunities that cities have to offer. Most importantly, this concept includes the right to equal access to the power to collectively shape and have a say over the process of urbanization and life in the city (Cutts \& Moser, 2015).

The concept of this right has been the rallying cry of progressive development advocates in third world countries, seeking a development approach that is based on equity and social justice. I discuss how clientelism undermines this understanding of citizenship.

\section{Clientelism in Argentina}

Greater Buenos Aires, the focus of this research, holds $25 \%$ of the country's population, contains an industrial park that represents $75 \%$ of the total employment in the province of Buenos Aires, has $60 \%$ of the country's voters, and has the highest level of unemployment and informally employed workers (Szwarcberg, 2015). This region sits side by side with the capital city, creating tensions between informal workers and tenements with the city itself. In this region, unemployment is an epidemic. Since the launch of Menem's convertibility plan, unemployment has increased by 200 percent (Iñiguez and Sanchez, 1995; Beccaria and Lopez, 1996). Unemployment impacts poor populations worse than other groups. Without a financial safety net, poor families that suffer chronic unemployment are unable to feed themselves or cover basic expenses (Auyero, 2000a). To multiply their problems, if families fall ill, they are met by a deteriorating healthcare system. Under centralization in neoliberal economic policies, fewer resources are left for hospitals and healthcare in the municipalities (Pribble, 2013). 
Under the economic restructuring of Menem, Greater Buenos Aires suffered social dislocations.

On the other side of hyper unemployment, poverty, and a degrading healthcare system, wealth is concentrated in high-income groups. It is estimated that the "poorest 40\% of the families in Greater Buenos Aires received 11.7\% of the total income in 1989. The wealthiest 10\% of the families, on the other hand, received 41.6\%" (Acuña, 1994). Measured in terms of "unmet basic necessities, which details the level of housing, sanitation, ability to attend school, and employment, $35 \%$ of the population in the province lives with unmet basic needs (INDEC 2001-2010). When confronted with uneven wealth concentration, hyper unemployment, and chronic poverty, how do the poor survive? Poor residents survive in systems of clientelism. These sectors are left without resources, without employment, and are steadily neglected by the state. In light of scarce resources, they bargain with the state in order to receive basic goods.

Clientelism, or the relationship between the state and clients to meet basic needs, disproportionately affects the poor in the neighborhoods seen in foundational ethnographies for my research (Auyero, 2000a; Szwarcberg, 2015; Weitz-Shapiro, 2008). As such, this research focuses on the poor of greater Buenos Aires who populate the areas adjacent to the capital city.

In this section I analyze the relationship of the clientelist mediators, or brokers, to their community. Brokers are the key in operationalized clientelism. They have strong community connections, and these appear to give citizens more access to the products of urbanization. Brokers' methods, however, manipulate their network ties and ultimately undermine community capacity. 
Acting on behalf of the state, brokers leverage their power to meet individual needs for basic infrastructure in exchange for political favors and the opportunity to gain power. The marginalized have no options available and are forced to solve their everyday survival needs through "personalized political mediation." Their mediation is a juggling act of attending political rallies, supporting brokers, and exchanging favors to solve basic problems of food shortages, childcare, and community infrastructure (Auyero, 2000a).

Mediation between citizens and the state occurs on a daily basis through brokers. Brokers are the members of society who give government aid a name and a face. As people on the ground, they manage the distribution of goods to citizens, fulfilling unmet needs of the community, and navigate the complex relationships between the state and its welfare program distribution.

Brokers represent the state in poor neighborhoods and often have deep social connections within the community. Auyero describes their role based on his experiences in Villa Paradiso:

Brokers stand guard over the critical junctures and synapses of relationships which connect the local system to the larger whole. Their basic function is to relate community-oriented individuals who want to stabilize or improve their life chances, but who lack economic security and political connections, with nationoriented individuals who operate primarily in terms of complex cultural forms standardized as national institutions, but whose success in these operations depends on the size and strength of their personal following (Auyero, 2000a). Brokers are the bridge between the national level and the individual. The state, or national level, offers security and stabilization. Individuals offer political support, loyalty, 
and affiliation. Brokers rest in the middle of this complex relationship and navigate between the two parties.

Prominent members of the community are frequently solicited to become brokers. Szwarcberg explains this process in the story of a man named Pino, a community leader, who was offered a position within the state from Ortega, a local government official. Pino ran a soup kitchen. After seeing Pino's successful management, Ortega offered him a job in the municipality as a broker. Pino was offered stability and upward mobility. In exchange, he must use his community knowledge and presence for those that have granted him security.

Ortega recruited Pino to mobilize voters for his party in exchange for full-time work in politics. Since his appointment, Pino has worked full time to solve voters' problems, mobilizing them to participate at rallies and support Ortega's party in elections (Szwarcberg, 2015).

Brokers, like Pino, are working within the community on a daily basis to meet needs. In the process, they gain personal stability and support an elected official.

The experience of community leaders being co-opted to serve state purposes is not uncommon. In another neighborhood, Szwarcberg explains how Matilde and Alicia began their political careers as community organizers. Based on their deep community connections, interactions with residents, and experience in distributing goods from the welfare program, these women succeeded in constructing a party network that they mobilized for rallies (Szwarcberg, 2015). From their strong community ties, they were able to become brokers in the community. They reorganized the community in order to fulfill the political needs of the Peronist party. In return for their participation in rallies 
and votes, Matilde and Alicia were able to help distribute additional welfare packages from the state. In the process, Matilde and Alicia became community leaders and gained stability themselves in the role of broker.

Brokers walk the complex line between citizens, their needs, and state assistance. Brokers are often a part of the community itself and have an intimate knowledge of the needed resources. They also are working on behalf of the state to gain constituents. While they have strong community ties, brokers' principle purpose is to gain political power for the party they support. Brokers ability to perpetuate an uneven power structure is the fundamental problem of clientelism. The political elites manipulate residents through the distribution of goods for votes. The broker's function ultimately undermines citizens' ability to participate in their own community.

The broker's primary function is to mobilize public support for political candidates. They do this by providing physical goods, exchanging community favors, and distributing welfare. Often brokers are affiliated with the Peronist party, which has a history of advocating for social justice and welfare. Founded originally by Juan Peron and his wife, Evita, the Peronist name is a unifying cry in politics to be "of the people and for the people." They gained the vote of the people by creating a social welfare net and unifying the "descamisados," women, and unions to their cause. Politicians today continue to "practice Evita" in a distribution of welfare goods in order to gain political power (Auyero, 2000a). Brokers are known in the community for their ability to provide. They are on the ground everyday, are community members themselves, and become a representation of state welfare in these sectors. 
These community organizers turned brokers are not always affiliated with a specific party. In an article revisiting the theme of clientelism Szwarcberg shows that the brokers lend their support to different parties depending on who can best meet their needs (Szwarcberg, 2012). In this sense, community brokers are leveraging collective individual power to receive goods from the state. They advertise their political support, and politicians vie for their votes. A broker's role here is to find a politician desperate for political support, then leverage basic necessities out of them in exchange for political favors. Brokers are still in a position of manipulation. They control the scarce resources of the community (e.g. voting power) and sell it to the highest bidder. In the process they receive temporary personal stability, but the community at large remains trapped in a dependency cycle (Auyero, 2000b; Weitz-Shapiro, 2014).

Clientelism exists in poor communities because of resource scarcity and because poor residents votes can be bought. Poor communities afflicted with hyper unemployment, low social capital, lack of welfare, and a degrading public health system have little to no options for assistance. This void in resources creates space in a community where brokers can intervene.

In neighborhoods now almost devoid of social organizations, where dwellers are increasingly isolated from each other, individuals have few networks for obtaining information. Brokers and their inner circles, in contrast, have access to helpful, even vital information (Auyero, 2000b).

Clientelism provides a network where there is none. In the void of resources, brokers manipulate residents to gain political power. The patrons, or brokers, of 
clientelism are able to buy political support because the residents have nothing left to offer except their vote.

How the community views brokers is divided and complex. Much of what the brokers do for the community is useful, such as providing food and infrastructure. To residents, the clientelist practices are more than the technocratic relationship between the state to the individual filtered through a broker. Clientelism is more than strictly a power relationship. Instead, these types of relationships are "habitual practical knowledge" (Auyero, 2000a). Residents commonly are thankful this relationship exists at all and are grateful for all the resources brokers bring to the community.

In response to the brokers, community members experience a gratitude complex, in which they receive goods, yet know that eventually the favor will have to be returned. In his interviews Auyero demonstrates this idea with a woman named Coco. He asked"

So, when Matilde [community broker] gets the medicine you need, does she come and tell you, "you have to come with me to the rally?" Coco responded, "No, I know that I have to go to her rally in order to fulfill my obligation to her, to show my gratitude. Because, if I do not go to her rally, then, when I need something, she won't' give it to me" (Auyero, 2000a).

Residents understand the exchange that must occur and do not view it as if the brokers are grabbing for power. Instead, community members feel that brokers are genuinely trying to help and they must return the favor. This furthers the cycle of dependence of clientelist structures. Anything accomplished in the neighborhood ultimately is attributed to the brokers due to the gratitude cycle. 
Under the influence of the relationship between brokers and the community, the line between what the state accomplishes and what residents do themselves becomes unclear. For example, Villa Paradiso, like many shantytowns, suffered from poor infrastructure. The roads were all dirt, full of gigantic potholes, waste in the streets, and trenches of mud during flooding season. The primary streets became impassable. When the road was paved, two narratives about the event arose.

One narrative focused on the collective action of the community and their ability to organize and labor towards the common goal of paving the roads. The other, statist, narrative explains that the roads were paved through the involvement of the municipality, specifically one broker or politician. In this narrative one person is given credit for what a whole community may have accomplished. The ability of residents to organize and move themselves towards a common goal is brought into question through the existence of clientelism (Auyero, 2000a). In communities where resources are scarce, the state takes credit for the accomplishment, further controlling the residents themselves.

The state ultimately directs the narrative in communities who experience clientelism. The residents of the community may have contributed to the paving of the roads, but they experience the debt of gratitude and give credit to the broker who made it possible. Neighborhoods do not have much access to resources or information, and further rely on the state to tell them what has happened. The ruling narrative relies on citizen dependence on brokers who control not only physical resources, but also information. Brokers management of scarcity manipulates residents (Szwarcberg, 2015; Weitz-Shapiro, 2014). The brokers mobilize a community to achieve a goal or support a politician. Then, once the goal comes to fruition or a politician to power, the broker takes 
credit and further supports their political party. Brokers have more access to information and resources, and as such are able to manipulate the involvement of residents to meet their needs.

If families do not repay the political party that supported them, devastation occurs. This means that if, for example, a family does not return the favor through attending rallies or voting, ailing members do not receive necessary medications, family members and friends lose employment, and basic food packages are not received. "While distributing bags of food two weeks before intraparty elections, the [broker] told recipients, 'Remember you have to vote on June 29. If not, you are automatically crossed off the list!" (Oliveros, 2016; Szwarcberg, 2015). The consequence of not participating in the election or rally results in the withholding of welfare. Attendance at rallies is monitored to regulate who receives physical goods (Oliveros, 2016). Residents who do not comply run devastating risks as they go with primary needs unmet.

Brokers are the key in operationalized clientelism. While brokers and their strong community ties appear to give citizens more resources, the relationship is a manipulative control of scarce resources in an isolated network. Brokers do help residents to obtain food packages, medicine, and infrastructure in their communities. These objectives, however, are achieved in a way that undermines community collaboration and manipulates residents. In the end, it is only the broker ends up with power and stability long term instead of the community.

\section{Right to the City}

Lefebvre originally published his thoughts on the right to the city and ideas around public space in France just preceding the global economic crisis of the 1970s. In post war 
France, a state-centered developmental model took precedence. Lefebvre's ideas existed in a western era of "intensifying interdependence and interconnectedness" where capitalism and neoliberal economic policies were prominent (Brenner, 1997). In his original context, Lefebvre saw the existing practices of capitalism and how they affected space. In the capitalist mindset, he said that there is a "violence directed towards a space in which social relations are rationalized, partitioned, and territorialized within an objectified grid" (Brenner, 1997). Lefebvre argued that global intensification generates fragmentation in social spaces,

How and why is it that the advent of a world market, implying a degree of unity at the level of the planet, gives rise to a fractioning of space - to proliferation nation states, to regional differentiation and self-determination, as well as to multinational states and transnational corporations which, although they stem from this strange tendency towards fission, also exploit it in order to reinforce their own autonomy? Towards what space and time will such interwoven contradictions lead us? (Lefebvre, 1974)

Lefebvre suggests that social spaces within contemporary capitalism are becoming politicalized (Lefebvre, 1974). The state's primary function is "no longer simply to secure growth, but to reproduce relations of domination" (Lefebvre, 1996). As the world has moved from an industrial to urban society, social space has become more fragmented. In the midst of fragmentation and contradicting narratives between state and global players, Lefebvre proposes his idea of the right to the city.

The "right to the city" is a "demand [for] a transformed and renewed access to urban life" (Lefebvre, 1996). David Harvey explains this concept of access, 
The right to the city is far more than the individual liberty to access urban resources: It is a right to change ourselves by changing the city. It is, moreover, a common rather than an individual right since this transformation inevitably depends upon the exercise of a collective power to reshape the processes of urbanization. The freedom to make and remake our cities and ourselves is, I want to argue, one of the most precious yet most neglected of our human rights (Harvey, 2012).

In the midst of socially fragmented spaces, the right to the city proposes that spaces are socially produced and owned. Beyond that, citizens have a right to shape the space they live in instead of having the state shape it for them.

While appeals to the right to the city focus on practical aspects (e.g. access to urban resources), Harvey emphasizes the fundamental drive of this right. The right to the city is a mutually benefitting ideal where all citizens shape their environment and in turn are impacted by the spaces they create. It is an individual and collective right to selfdetermination and the ability to shape one's own future.

Applying Lefebvre's idea of the right to the city and social space in Argentina is not a stretch. The formational setting in France of the right to the city parallels the setting in Argentina. Argentina also suffered from social and economic fragmentation in the context of neoliberalism. Just as Lefebvre used the right to the city to intercede into public spaces and give citizens control of their environment, the right to the city in the Argentine context intervenes in a space where citizens are being denied the ability to collaborate as a community. 
In both France and Argentina the country's rhetoric around marginalized communities is dominated by the state. The right to the city presents an alternative narrative to promote the importance of citizens' voices. Collective citizen action is significant when it occurs in social spaces that communities create. The right to the city is a human right, aimed at collaborative action of a community to have access to the benefits of urbanization such as food, education, health, transportation, and community action. It implies the decisive action of citizens to shape their community and, in turn, be shaped by the spaces they create.

The right to the city is more a conceptual ideal than a strategic plan for communities. As Lefebvre describes in his contemplation of the right to the city, if people, whether individuals or groups, are excluded from urban areas, they are excluded from all of civilization and society. The right to the city stands up against practices of segregation that exclude citizens from basic access to the benefits of urbanization (Lefebvre, 1996).

A citizen having a "right to the city" has become the rallying cry in development in the Global South. Development around this idea focuses on marginalized members of society and how they are excluded in their access to urban goods (Brown, 2013; Cutts \& Moser, 2015; Holston, 2009). In an ideal world, all citizens regardless of social class, nationality, income, and family would be able to have equal access to all goods. A man who lives in a shantytown could walk down the same street as a government official and feel equally safe and secure. Men from differing classes would both have access to the security and physical benefits that cities make available, such as housing, parks, and commerce. Such equality seems impossible in our world today. As such, most applied 
definitions of a right to the city focus on the material goods, or the physical products of urbanization:

People have right to the city when they have access to basic needs such as water, shelter, electricity, health facilities, security of tenure, food, etc... which protects many people especially poor urban dwellers living in slums and low income residents from being evicted. ...In many countries urban residents and especially poor people are not considered as people who can contribute to their own development. The city or state always ignores their input (Brown, 2013). The right to the city is a call to equality and basic human dignity. It is an attempt to restore basic human rights to marginalized members of society who have fallen to the wayside in the process of industrialization of the urban area, suffered under neoliberal practices, and who deserve access to basic resources. This right enables the people to shape their own community and have autonomy and self-determination.

In the context of greater Buenos Aires, the right to the city would signify a transformation of lifestyle for the disenfranchised. Access to the good of urbanization would eliminate chronic unemployment and increase the wellbeing of every family. In their access to create safe public spaces, the right to the city promotes a community's ability to become socially mobile and operate in an economy of surplus instead of scarcity. The right to build community capacity and have a right to the city is undermined by clientelism in greater Buenos Aires.

Clientelism fundamentally removes citizen's ability to participate and shape their city after their own desires. There is no space to be proactive about their community, for 
the residents are concerned more about playing the game to receive food and exchanging their basic rights to receive it. As Brown points out,

The critical difference is that the right to the city can be effective only when city dwellers become active agents of change rather than recipients of dispensed benefits... The implication is that development decisions about the city are not confined to the city hall but are the result of debate and deliberation among the citizens (Brown, 2013).

The technocratic exchange of clientelism does not permit members to be active agents of change.

Instead of deliberating and moving forward with their future, citizens live in fear of going without basic necessities. As such, they exchange their votes, time, and community for the power politics of a clientelist relationship. The democratic process of government is undermined when a citizen's vote no longer represents their voice. Their vote is nothing more than a desperate plea to save their family from hunger. Clientelism functions in an isolated environment to control scarce urban resources. It stands in direct opposition to the right to the city where citizens have access to basic goods and the ability to self mobilize for the good of the community.

From an academic standpoint, there is agreement that clientelism compromises democracy (Auyero, 2000a; Szwarcberg, 2015; Weitz-Shapiro, 2014). From the standpoint of the clients themselves, however, it appears as if the brokers are giving them more access to the city. As discussed previously, clientelist networks are sort of a poor country's welfare state. Reform such systems too soon, the minority asserts, and you run the danger of depriving 
'clients' of the only organizations and networks capable of responding to their needs (Brusco et al., 2004).

The view of clientelism from the people themselves makes the issue more muddled.

The brokers are able to help the community to pave roads, receive welfare, and facilitate the distribution of goods in the area. The brokers themselves are often community members who work with the state to help the neighborhood in which they grew up. Citizens get their needs met through the brokerage system. The rallies and political parties provide a safe community space for the public to gather compared to a normal level of fear of the streets (Auyero, 2000a). The perceived benefits of the residents, however, do not negate that clientelism denies them rights at a fundamental level.

The benefits of the clientelist structure are like Band-Aids over an injury that needs stitches. On a daily basis, citizens are deprived of basic necessities. What should be access to food, public spaces, and the ability to collaborate towards a future in the community becomes a conditional exchange. Worse yet, they are exchanging one of their few political powers, their vote and presence, in order to receive these goods. The manipulation inherent in clientelism robs citizens of their voices and undermines citizengovernment accountability. While clientelism may have immediate perks and functions in an emergency state, long term it deprives citizens of their ability to participate in their own community effectively.

\section{Conclusions}

Throughout this paper I analyzed clientelism through the lens of the right to the city. In terms of a larger conversation, the analysis of clientelism through the lens of the 
right to the city also further defines what this right is. Clientelism is a perversion of the right to the city. Brokers appear to give their constituents more access and ability to build their environment, but in the long run inhibit citizens from engaging in a democratic fashion.

At its core, clientelism undermines democracy and removes citizens' capacity to use their own voice in shaping the life of the city (Auyero, 2010; Weitz-Shapiro, 2014). In exchanging their vote or favors to for basic necessities, civilians keep brokers in power, only strengthening their control of scarce goods. From the standpoint of citizens as a whole, these relationships might be seen as helpful and caring, but at a fundamental level they are a power dynamic that undermines a citizen's right to their own city.

Clientelism is successful in bringing resources to isolated communities. Under the fragmented political centralization of the government, there was not enough state welfare to cover the poor population. Brokers distribute these scarce resources. They leverage the individual voting abilities of residents to receive physical goods from the state. In exchange, the brokers are able to be upwardly mobile and receive economic stability for themselves and their families. In poor communities that have been isolated from the heart of the city, brokers and government officials not only control the few physical resources available, but they also control the information network. In their seemingly non-coercive domination, brokers perpetuate a dependence cycle of the community on the state. In furthering the cycle of state-dependence, clientelism denies citizens autonomy and the ability to build their own future.

Decisive ending of clientelism is not possible. For one thing, those in power perpetuate its pervasiveness on a daily basis. The isolation of poor communities from the 
rest of the city also deprives them of the resources to overturn set power structures. As long as citizens depend heavily on their relationships with brokers for their well-being, clientelism is dangerous to remove. While clientelism undermines community capacity, the alternative would not mean immediate democracy, but instead a system of neglect. Although the distribution of food, paving of roads, and control of scarce resources is dangerous to the state of democracy in the country at large, its removal would mean devastation for the citizens themselves (Brusco et al., 2004). If all systems of clientelism were to be removed tomorrow, isolated communities would not immediately become poster children for democratic politics. Instead, they would suffer from further neglect and lack of resources.

Further research should look into grassroots community initiatives where clientelist structures exist in greater Buenos Aires today. Investigation of other networks available to isolated communities, their ability to mobilize, and an understanding of strengths in individual communities are necessary if these regions are to transition away from clientelism. Grassroots initiatives based on these investigations have taken ahold of marginalized communities across Latin America. While we do not know their success long term, they encourage citizens to participate and fight for their inherent rights. It is critical that more information is collected surrounding clientelism in the continuing conversation around citizenship and urban spaces. In development in Latin America, clientelism puts democracy and the livelihoods of residents at risk. Power structures such as clientelism must be examined closer as Argentina and other Latin American countries continue to develop. Citizens must be given a right to the city in the process of continual urbanization. 


\section{References}

Acuña, C. M. (1994). Democracy, Markets, and Structural Reform in Latin America: Argeninta, Bolivia, Brazil, Chile, and Mexico. New Brunswick, N.J.: Transaction Publishers.

Amadasi, E. (1999). La Pobreza en la Argentina. Buenos Aires: Caritas.

Auyero, J. (2000a). Poor People's Politics: Peronist Survival Networks \& The Legacy of Evita. Duke University Press.

Auyero, J. (2000b). The logic of clientelism in Argentina: An ethnographic account. Latin American Research Review, 35(3), 55-81.

Auyero, J. (2010). Visible Fists, clandestine kicks, and invisible elows: three forms of regulating neoliberal poverty.

Beccaria, Luis, and Nestor Lopez. (1996). Notas sobre el compartamiento del mercade de trabajo urbano. Sin trabajo: Las caracteristicas del desempleo y sus afectos en la sociedad Argentina. Buenos Aires: Losada.

Brenner, N. (1997). Global, Fragmented, Hierarchical: Henri Lefebvre’s Geographies of Globalization. Public Culture, 10(1), 135-167.

Brown, A. (2013). The Right to the City: Road to Rio 2010. International Journal of Urban and Regional Research, 37(3), 957-971.

Brusco, V., Nazareno, M., \& Stokes, S. C. (2004). Vote Buying in Argentina. Latin American Research Review, 39(2), 66-88.

Budds, J. (2013). Water, Power, and the Production of Neoliberalism in Chile, 19732005. Environment and Planning D: Society and Space, 31(2), 301-318. 
Cutts, A., \& Moser, S. (2015). State-community collaborative strategies to enable the right to the city in Argentina. Habitat International, 49, 243-250.

Dello Buono, R. A., \& Lara, J. B. (2006). Imperialism, Neoliberalism and Social Struggles in Latin America (1). Boston, NL: BRILL. Retrieved from

Grassi, E., \& Noberto, A. (2005). Neo-liberalism in Argentina: Social Policy, Welfare and the Condition for the Development of Social Work. In Globalisation, Global Justice and Social Work (pp. 22-30). Abingdon: Routledge.

Harvey, D. (2012). Rebel Cities: From the Right to the City to the Urban Revolution. London: Verso.

Holston, J. (2009). Insurgent Citizenship in an Era of Global Urban Peripheries. City \& Society, 21(2), 245-267.

Jenkinson, O. (2016, September 3). Shanty town growth spurs action. Retrieved November 11, 2016, from http://www.buenosairesherald.com/article/221022/

Lefebvre, H. (1996). Writings on Cities. Malden, MA: Blackwell Publishing. Lefebvre, H. (2014). Urban Revolution. Minneapolis, US: Univ Of Minnesota Press. Medeiros, C. A. de. (2011). The Poltiical Economy of Institutional Change and Economic Development of Latin American Economies. Journal of Economic Issues, 45(2).

Oliveros, V. (2016). Making it Personal: Clientelism, Favors, and the Personalization of Public Administration in Argentina. Comparative Politics. 273-391.

Paradiso, E. (2016). Football, clientelism and corruption in Argentina: an anthropological inquiry. Soccer \& Society, 17(4), 480-495. 
Pribble, J. E. (2013). Slow Progress Towards universalism. In Welfare and Party Politics in Latin America (pp. 133-158). Cambridge: Cambridge University Press.

Ratliff, W. E., \& Fontaine, R. W. (1993). Argentina's Capitalist Revolution Revisited: Confronting the Social Costs of Statist Mistakes. Stanford University: Standford, CA: Hoover Instituion on War, Revolution, and Peace.

Rodríguez-Boetsch, L. (2005). Public service privatisation and crisis in Argentina. Development in Practice, 15(3-4), 302-315.

Stokes, S. C. (2011). Political Clientelism. Retrieved from http://www.oxfordhandbooks.com/view/10.1093/oxfordhb/97801996044 56.001.0001/oxfordhb-9780199604456-e-031

Szwarcberg, M. (2012). Revisiting clientelism: A network analysis of problemsolving networks in Argentina. Social Networks, 34(2), 230-240.

Szwarcberg, M. L. (2009). Making local democracy: Political machines, clientelism, and social networks in Argentina. ProQuest, Ann Arbor MI.

Szwarcberg, M. L. (2015). Mobilizing Poor Voters: Machine Politics, Clientelism, and Social Networks in Argentina. Reed College: Cambridge University Press. 2001-2011: The Making of a Crisis. (n.d.). Retrieved from http://www.argentinaindependent.com/currentaffairs/analysis/20012011-the-making-of-a-crisis/

Vilas, C. M. (2006). Neoliberal Meltdown and Social Protest: Argentina 2001-2002. Critical Sociology, 32(1), 163-186. 
Weitz-Shapiro, R. (2008). Choosing clientelism: Political competition, poverty, and social welfare policy in Argentina . Columbia University. New York.

Weitz-Shapiro, R. (2014). Curbing Clientelism in Argentina: Politics, Poverty, and Social Policy. Brown University: Cambridge Univesity Press.

Williamson, J. (1990). Latin American Adjustment: How Much has Happened? Washington, DC: Intsitute for International Economics. 